\title{
The direct and interactive effects of store-level promotions on impulse purchase: moderating impact of category familiarity and normative influences
}

Authors

PAURAV SHUKLA

Glasgow School for Business \& Society, Glasgow Caledonian University London, 40 Fashion Street, Spitalfields, London E1 6PX, UK

\section{MADHUMITA BANERJEE}

Department of Marketing, University of Strathclyde, Glasgow, UK

This is a pre-print version.

\begin{abstract}
Marketing literature conceptually and empirically establishes the direct effects of different variables on impulse purchase. However, the simultaneous interactions between variables influencing impulse purchase are yet to be studied. This paper measures the direct effects of store-level promotions, brand equity and price consciousness and also examines the interactive effects of store-level promotions and the moderating influence of category familiarity and normative influences. The results demonstrate the importance of simultaneous examination of interplay between different consumer and store level variables. Collectively the results provide substantial segmentation opportunities for manufacturers of branded goods and retailers.
\end{abstract}

\section{Keywords}


Store-level promotions, brand equity, price consciousness, category familiarity, normative influences, impulse purchase 


\section{The direct and interactive effects of store-level promotions on impulse purchase: moderating impact of category familiarity and normative influences}

\section{Introduction}

Today's retail stores are full of in-store sensory stimuli including perfectly aligned packaging, engaging displays, creative advertising and alluring promotion offers. These instore stimuli trigger unrecognized needs and desires and entice consumers to purchase unintended goods and, in turn, act impulsively (Inman et al., 2009). Rook and Fisher (1995) define impulse purchases as decisions which occur when a consumer experiences a sudden, often powerful and persistent urge to buy something immediately. These decisions are in contrast to the planned purchases (Ajzen, 1991) which are decided before entering a store. Impulse purchase behavior is found to be a persistent and distinctive aspect of consumers' lifestyles (Peck and Childers, 2006) with approximately $30 \%$ to $62 \%$ of all purchases being identified as impulsive in nature (Inman et al., 2009). Given the importance of impulsive decisions in the overall decision-making process and with the increasing number of purchase decisions being made in-store, it is critical to understand the factors driving consumers' instore impulsive purchase behavior.

This paper investigates the direct and interactive effects of store-level promotions. Store-level promotions are increasingly used for grabbing consumers' attention and also for offering a direct inducement (Ailawadi et al., 2006; Ailawadi et al., 2009). While store-level promotions may help in grabbing customers' attention, Chandon et al. (2009) emphasize the importance of consumer consideration. Chandon et al. (2000) and Lichtenstein et al. (1993) suggest that at the in-store level, consumer price consciousness and brand equity act as critical determinants of consumer consideration (Dyson, Farr and Hollis, 1996). Ailawadi et al. (2009) note that store-level promotions reflect low price positioning for many brands. Such 
store-level promotions on branded products can not only act as triggers for impulse buying but also be attractive propositions to price conscious consumers. Taken together, all of the above raise some interesting questions, such as: Will a well-known national brand available with store-level promotions induce consumers to buy impulsively? Will price conscious consumers become impulsive in the presence of an inducement like store-level promotion? Extant research by Rook and Fisher (1995) and Inman et al. (2009) investigates individual factors impacting on impulse purchase. This study however, extends the debate by examining the simultaneous interaction effects of variables influencing impulse purchase.

A second aim of this study is to examine the moderating influence of category familiarity and normative influences on consumer impulse purchase. Consumers find it difficult to make purchase decisions based on brand preferences due to increasing brand proliferation and often make their final decisions based on product category level. Moreover, extant research suggests waning brand loyalty among most consumers and an increasing preference focused at the category level (Graeff, 2007). Thus, category familiarity may play a moderating role in consumer brand consideration (Rao and Monroe, 1988). Consumers often acquire products because of what the products mean to them and to the members of their social reference groups (Shukla, 2010). Extant research suggests that social norms and expectations play an important role in consumer consideration (Bearden et al., 1989).

This study contributes to the literature on impulse buying decisions by developing a conceptual framework that incorporates the direct and interactive effects of store-level promotions on the relationship between brand equity, price consciousness and impulse purchase. The moderating effects of category familiarity and normative influences on impulse purchase are empirically tested. This simultaneous examination of the direct, interactive and moderating effects provides a comprehensive understanding of impulse purchase decisions. For retail managers and manufacturers, knowing which factors drive consumer impulse 
purchase at store-level is of critical importance. The study findings will help retail managers and manufacturers in making informed choices about the drivers of impulse purchase at the store-level and provide an opportunity to develop integrative marketing strategies at the storelevel to drive impulse purchase.

\section{Conceptual Framework}

Presence of an attention inducing stimuli such as point of purchase displays and storelevel offers can trigger positive affective appraisal among consumers regarding the particular product being promoted (Parker and Tavassoli, 2000). Such processing can have an influence on consumers' brand image perceptions and price consciousness (Chandon et al., 2000; Lichtenstein et al., 1993). Blattberg and Wisniewski (1989) posit that consumers hold strong views on the price of the brand and its value in consumption. Thus, this study argues that consumer attention (i.e. store-level promotion) and consideration variables (i.e. price consciousness and brand equity ) can significantly increase impulse purchase decisions. Consistent with the factors that increase attention and consideration that in turn lead to impulse purchase, we also posit that attention inducing stimuli such as store-level promotions may moderate the relationship between consumer consideration variables. Figure 1 presents the conceptual model for the study.

Figure 1 here.

\subsection{Direct effect on impulse purchase}

\subsubsection{Store-level Promotion}

Despite their high fixed costs, store-level promotions (i.e. in-store point of purchase displays, in-store flyers, store-level offers and contests) are a source of additional margins. 
They help reinforce a low-price positioning and are a key to performance in today's retail environment (Ailawadi et al., 2009). Several household-level scanner data studies offer clear evidence of the positive effects of store-level promotion on purchase behavior. Using data from two large supermarket stores, Walters and MacKenzie (1988) show the positive impact of store-level promotion on store traffic and sales. Walters (1991) extended these findings further by considering two stores from competing retailers and demonstrated that store-level promotion in one store had a negative influence on sales in the competing store. Kamakura and Kang (2007) measured the influence of store-level promotions at chain-wide level with a specific focus on immediate effects. Their findings also demonstrate the significant positive impact of store-level promotion on purchase behavior.

While the store-level promotions seem beneficial overall, the results relating to their impact on triggering impulse purchase are decidedly mixed. In an earlier study focusing on US consumers' food purchasing behavior, Cox (1970) found positive but non-significant relationship between store-level promotions and impulse purchase. However, in a study of fifteen supermarkets in South Africa, Abratt and Goodey (1990) found consistent rates of impulse purchase associated with in-store stimuli. However, Parker and Tavassoli (2000) note that little consideration has been given to consumers' view of store-level promotions and how consumers incorporate stimuli such as store-level promotions into their shopping behaviour. There have been calls for further research examining the impact of store-level promotions on purchase behavior (Ailawadi et al., 2009). Given that, retailers and manufacturers are diverting a growing proportion of their promotional budgets from traditional out-of-store media advertising to in-store promotions (Chandon et al., 2009), understanding their impact will assist retailers and manufacturers in making more informed decisions regarding how to influence consumer impulse purchase behavior. Additionally, based on the results of the large 
scanner data studies regarding the positive influence of store-level promotions on purchase behavior, it is hypothesized that:

$\mathrm{H}_{1}$ : Store-level promotions will have a significant, positive impact on impulse purchase behavior.

\subsubsection{Brand Equity}

Firms are increasingly recognizing brands as one of their most valuable assets (Aaker, 1991) and therefore intensifying the level of resources directed towards building and preserving them. The attributes possessed by the brand make the marketing of that brand distinctive, adds to the product's incremental value due that unique brand name (Srivastava and Shocker, 1991) and creates its equity (Keller, 1993). Rangaswamy et al. (1993) posit that brand equity has been defined in various ways focusing on different dimensions. The most accepted dimensions of brand equity are the ones suggested by Aaker $(1991 ; 1996)$ and Keller (1993). These include: brand loyalty, brand awareness, brand association and perceived brand quality. From a retailer's perspective, brands are highly important because they generate higher margins than their non-branded counterparts (Ailawadi and Harlam, 2004), have higher promotional lift (Ailawadi et al., 2006; Slotegraaf and Pauwels, 2008), are more effective in driving store performance, and help attract and retain customers (Ailawadi et al., 2009). From a customer's perspective, brand equity creates positive reactions, evokes familiar and strong associations in the memory (Keller, 1993) and build consumer trust (Rust et al., 2004). Keller (1993:8) proposes customer based brand equity as the "differential effect of brand knowledge on the consumer response to the marketing of the brand". The customer's overall brand knowledge is based on brand awareness and brand image (Keller, 1993). If a brand enjoys high awareness and commands a positive image, customers will respond favorably to the marketing actions (Keller, 1993), pay premium prices (Starr and Rubinson, 
1978), and enhance their search for the brand (Simonson et al., 1988). In case of an impulse purchase, a consumer does not plan to buy the product in advance. Therefore, in these situations, brand equity may act as a spark for positive brand associations and thus make it easier for consumers to evaluate and make the purchase decision (Dyson, Farr and Hollis, 1996). The ease of decision making due to positive brand equity may in turn trigger for impulse purchase. Thus, it is hypothesized that:

$\mathrm{H}_{2}$ : A product's brand equity will have a significant, positive impact on impulse purchase behavior.

\subsubsection{Price Consciousness}

Lichtenstein et al. (1993) define price consciousness as a buyer's unwillingness to pay a higher price or an exclusive focus on paying low prices. Prior research related to price consciousness suggests that consumers are price conscious in almost all their purchases and use various pricing reference points to make the final decision, including the last transaction price or the lowest and highest price (Alford and Biswas 2002; Sinha and Batra 1999). For price conscious consumers, obtaining a low price for the chosen product is more important than for non-price conscious consumers. They also tend to engage in higher levels of price comparisons than less price conscious consumers (Alford and Biswas 2002). Sinha and Batra (1999) argue that price conscious consumers have a strong desire to maximize the ratio of quality received to the price paid for any product and therefore may spend more time deliberating on their purchase decisions. Lastovicka et al. (1999) conclude that compared to other consumers, price conscious consumers are more disciplined in their purchasing pattern and tend to be less impulsive. It is assumed that the extra effort put in by price conscious consumers in the purchase process will result in lower levels of impulse purchase behavior. Thus, it is hypothesized that: 
$\mathrm{H}_{3}$ : Price consciousness will have a significant, negative impact on impulse purchase behavior.

\subsection{Interactive effects on impulse purchase}

Every year, companies spend billions of dollars on trade and consumer promotions (Chandon et al., 2009). Store-level promotions provide consumers an opportunity to buy branded products at a lower price. According to economic utility theory, promotions such as coupons and sale, may serve as economic incentives and in turn enhance the perception of value (Garretson and Burton, 2003). Therefore, this study posits that a branded product available at a lower price due to store-level promotion will increase a consumer's perceptions of value gain. Narasimhan et al. (1996) note that the savings and "trading-up quality" benefits of promotions are more salient for branded goods. Hence, consumers may perceive that they have gained acquisition and transaction utility and thus increased the overall value of the purchase (Thaler, 1985) by purchasing a branded product for a relatively reduced price because of the store-level promotions. Therefore, it is proposed that:

$\mathrm{H}_{4}$ : In the presence of a store-level promotion, brand equity will have a significantly higher impact on impulsive purchase behavior than in absence of store-level promotion.

In the current competitive retail environment, retailers often employ dynamic pricing across product categories (i.e., they change prices frequently) using complex pricing frameworks. Such complex pricing mechanisms may make it difficult for consumers to decide optimal price for the product they wish to purchase. Recent research in decision sciences and marketing suggests that when analyzing complex purchase information, consumers try to simplify their overall decision by focusing on cues which can offer immediate assistance 
(Durbach and Stewart, 2009). Store-level promotions may offer a strong cue for consumers in simplifying their final purchase decision. Price conscious consumers are highly focused on price elements (Lichtenstein et al., 1993), and therefore the effect of store-level promotion may be more pronounced for such consumers (Garretson and Burton, 2003). Store-level promotions offer an added opportunity to price conscious consumers to affirm their belief of getting a better bargain. Thus, the offer of immediate savings due to store-level sales promotions may increase price conscious consumers' likelihood to act impulsively. Therefore, $\mathrm{H}_{5}$ : In the presence of a store-level promotion, price conscious consumers will demonstrate significantly higher impulsive purchase behavior than in absence of storelevel promotion.

\subsection{Moderating role of category familiarity and normative interpersonal influence}

\subsubsection{Category Familiarity}

An emerging view in the field of behavioral decision research is that the expression of preference is often constructed at the category level rather than the brand level (Graeff, 2007). Grewal et al. (1998) observe that consumers with low familiarity extensively use extrinsic cues such as brand name or image as the attribute of significance, but when subjected with high familiarity, generate a much more complex schema. This complex schema development and analysis will result in increased level of systematic cognitive information processing rather than a heuristic processing (Ratneshwar and Chaiken, 1991). The systematic processing will involve higher levels of evaluation of brands with the particular category and comparatively more refined and rationale decision making among the consumers with higher familiarity. Hunt et al. (2013) in their study of mass customized products find a positive relationship between customers category familiarity and functional and symbolic involvement with the product. In this regard, this study posits that category familiarity will significantly 
moderate the relationship between the proposed antecedents and impulse purchase wherein, consumers with higher category familiarity will be less impulsive than consumers with low category familiarity. Additionally, Rao and Monroe (1988) opine that consumer familiarity affects price sensitivity and brand relevance. They argue that less familiar consumers are more likely to rely on price information than highly familiar consumers. Moreover, high familiarity will trigger better comprehension of the available extrinsic and intrinsic cues and results in a better developed schema of the available information (Rao and Monroe, 1988). Hence, it can be posited that consumers with high familiarity will be less impulsive than consumers with less familiarity. Taken together, all these studies suggest that a consumer's category familiarity moderates the effects of promotion-, price-, and brand related cues on impulse purchase decisions. However, there has been a lack of attention within the extant research regarding the effect of category familiarity on impulsive purchase behavior requires empirical support. The following hypotheses are proposed to empirically test the phenomenon:

$\mathrm{H}_{6}$ : The positive relationship between (a) store-level promotions; (b) brand equity and impulse purchase behavior and the negative relationship between (c) price consciousness and impulse purchase will be stronger among consumers with less category familiarity than among consumers with high category familiarity.

\subsubsection{Normative Influence}

Bearden et al. (1989) define "normative influences" as the tendency to conform to the expectations of others. The authors also suggest that consumers' consumption experiences are strongly influenced and shaped by their social environment and interpersonal interactions. Rook and Fisher (1995) argue that consumers' tendency of impulsiveness increases when acting on impulse is socially appropriate and rational. Much research on normative 
interpersonal influences in consumer decision making relies on the perspective offered by the theory of reasoned action (Ajzen, 1991). The theory of reasoned action by Ajzen (1991) suggests that subjective norms arise from individuals' predictions about how salient social reference groups will react to a particular consumption behavior (Bearden et al., 1989) and are coupled with the individual's motivation to comply with these normative expectations. For example, in the presence of other customers, a consumer may become self-conscious and buy a more expensive item than intended, in order to reflect his or her self-esteem. On the other hand, for the price conscious consumers, a branded product bought at a bargain price may make the consumer appear savvy in the eyes of other price conscious consumers. While Rook and Fisher (1995) argue that normative interpersonal influences moderate consumer impulse purchase decisions, they call for further research on such effects at store level. Even though researchers have long realized the importance of the direct influence of normative interpersonal influences in a variety of contexts (Bearden et al., 1989; Mourali et al., 2005; Shukla, 2011), researchers and marketers alike have mostly ignored the call for the moderating role played by normative influences in purchase decision making for multitudes of other behavioral variables (Verhoef et al., 2009). Consumers, who are highly influenced by others in that they continuously attempt to conform to the expectations of others, will tend to be more amenable to impulsive purchase to increase their conformity (Rook and Fisher, 1995). We posit that this effect will be more pronounced in the presence of a store-level promotion and also for known brands with strong brand equity. Moreover, price conscious consumers who are less affected by normative influences will be even less impulsive. Keeping in mind the earlier calls for the moderating role of normative influences and based on the above discussion, this paper examines the moderating role of normative interpersonal influence on the relationship between store-level promotions, price consciousness, brand equity and impulse purchase. The paper argues that consumers who are highly affected by 
normative influences will show a greater level of impulse purchase than consumers who are less affected by it.

$\mathrm{H}_{7}$ : The positive relationship between (a) store-level promotions; (b) brand equity and impulse purchase behavior and the negative relationship between (c) price consciousness and impulse purchase behavior will be stronger among high-normativeinfluence consumers than low-normative-influence consumers.

\section{Methodology}

A quantitative methodology employing a self-administered structured questionnaire measured and validated the hypothesized relationships. Low-end electronic products (i.e., USB sticks, webcams, low-end mp3 players, headphones, and low-end mobile phones) were selected because of the likelihood of high level category familiarity among respondents and increasing impulsive purchase associations of the product (Pilley, 2008). More than 700 consumers were contacted at main shopping areas of two cities in the South East of England. The main shopping areas were chosen because of high volume of retail traffic and store browsing and a wide assortment of product categories for retail sale. Consumers were asked about their experience of visiting electronic products stores (shopping areas in both cities had more than 10 different shops offering electronic products of various kinds) and asked to recall their prior purchase of electronic products (such as mobile phones, CD/DVD players, mp3 players, etc.). Data was collected over a five-week period, with survey teams rotating the location of interviews, the times of the day, and the days of the week to make the final sample representative. The final usable sample was 293 with a response rate of $41.86 \%$.of which $42 \%$ of the respondents were male, and the highest percentage of respondents $(54.9 \%)$ belonged to the 25-35 age group. Table 1 shows the scales used for measuring the four latent constructs. The store-level promotions scale was adopted from Chandon et al. (2000). Price 
consciousness was measured with a five-item scale adopted from Lichtenstein et al. (1993).

Brand equity items were adopted from Yoo and Donthu (2001). The impulse purchase construct was measured with three items from the construct developed by Weun et al. (1998). Adopted versions of the scales developed by Batra and Sinha (2000) were used for measuring the category familiarity construct. The normative influence construct was measured with four items from the scale developed by Lichtenstein et al. (1993).

Table 1 here

As Table 1 shows, the items used for measuring the latent constructs in the model show values above the recommended level for both composite reliability and average variance extracted (AVE). For all scales, the factors loadings were above 0.5 and significant $(p<$ 0.001 ), satisfying the criteria for convergent validity. Discriminant validity was assessed using the test developed by Fornell and Larcker (1981). This test suggests that a scale possesses discriminant validity if the AVE by the underlying latent variable is greater than the shared variance (i.e., the squared correlation) of a latent variable with other latent variable. As Table 2 shows, this criterion was met by all the variables in the study; no correlation exceeds the square root of the AVE. The totality of these tests provides strong evidence for reliability and validity of the construct measures.

Table 2 here

\section{Analysis and Results}

\subsection{Analysis of direct and interactive effects on impulse purchase}

Ping's (1995) guidelines were followed for the evaluation of structural models with interaction terms. Single scores were created for each of the latent variables involved in multiplicative interactions (store-level promotions, price consciousness, and brand equity). The interaction terms were created by multiplying the single scores. For example, the storelevel promotions score was multiplied with the price consciousness score to create a new 
variable: the price consciousness $\times$ store-level promotions interaction term. The factor loadings, error variance, and factor variance estimates obtained were fed into Ping's (1995) equations. This approach generated estimates of the error variances and factor loadings for both interaction terms. Two nested models were specified, using the estimates for the loadings and the error variances for the interaction terms. In both models, the loadings and error variances for the interaction terms were fixed at their previously estimated values. First, a restricted model was run in which the $\gamma$ parameters linking the interaction terms to impulsive purchase were fixed at zero, and the remaining $\gamma$ parameters were freely estimated. Second, an unrestricted model was run in which the $\gamma$ parameters originally fixed at zero were freed. As Table 3 shows, moving from a restricted to an unrestricted model resulted in a decrease in chi-square of 39.4, with an associated 2 degrees of freedom. The improvement in fit is significant at $p<0.001$. Furthermore, the other fit measures, including root mean square error of approximation (RMSEA), goodness-of-fit index (GFI), non-normed fit index (NNFI), and comparative fit index (CFI), improved substantially, suggesting that the unrestricted model is superior to the restricted model.

\section{Table 3 here}

Table 4 reports standardized parameter estimates and their t-values for the structural model. As predicted, store-level promotions had a positive effect on impulse purchase behavior $(\beta=0.13, t=2.11)$, providing support to $\mathrm{H}_{1}$. In support of $\mathrm{H}_{2}$, brand equity was found to have a strong positive impact $(\beta=0.39, \mathrm{t}=2.31)$. However, contrary to predictions, price consciousness did not have a significant impact on impulse purchase behavior $(\beta=-$ $0.07, \mathrm{t}=-0.70$ ), thus not supporting $\mathrm{H}_{3} . \mathrm{H}_{4}$ suggests that store-level promotions positively moderate the relationship between brand equity and impulse purchase. This result was supported $(\beta=0.19, \mathrm{t}=3.04)$. As hypothesized in $\mathrm{H}_{5}$, a strong and significantly positive 
effect of store-level promotions on the relationship between price consciousness and impulse purchase was found $(\beta=0.66, \mathrm{t}=5.93)$.

Table 4 here

\subsection{The moderating effects of category familiarity and normative influence}

In line with the procedure used by Grewal et al. (1998), respondents who scored above the median value were treated as the group with high category familiarity $(n=103)$, and respondent with less than the median scores were treated as the group with less category familiarity $(n=190)$. With regards to normative influence, the same procedure was employed to identify respondents who were in the high-normative-influence $(n=144)$ versus lownormative-influence $(n=149)$ groups.

Table 5 here

To assess the moderating effects, the structural models for the two moderating variables were also tested by estimating and comparing the restricted and unrestricted models, as discussed previously. As illustrated in Table 5, a significant improvement was observed when moving from a restricted to an unrestricted model across all measures. The chi-square difference was significant $(p<0.01)$ for all variables. The significant difference in chi-square suggests the presence of a moderating effect. The unrestricted models were used to test the hypotheses related to the moderating variables because they presented a better-fitting model in all cases. Table 6 provides the path coefficients with related fit statistics and demonstrates the moderating impact of category familiarity and normative influence on the relationship between store-level promotions, price consciousness, brand equity, and impulse purchase.

Table 6 here

As predicted, category familiarity had a stronger moderating influence among consumers with less category familiarity $(\beta=0.32, t=2.11)$. However, the impact of category 
familiarity was non-significant among the consumers in the high category familiarity group, and thereby, demonstrating partial support to $\mathrm{H}_{6 \mathrm{a}}$. The hypothesized positive moderating influence of category familiarity on the relationship between brand equity and impulse purchase was partially supported $\left(\mathrm{H}_{6 \mathrm{~b}}\right)$; consumers with less category familiarity $(\beta=0.26, \mathrm{t}=$ 1.98) demonstrated greater impulsive purchase tendencies than consumers with high category familiarity. The group with less category familiarity had a stronger impulse purchase inclination $(\beta=0.52, \mathrm{t}=2.60)$ than the group with high category familiarity $(\beta=0.43, \mathrm{t}=$ 2.34), in support of $\mathrm{H}_{6 c}$. Normative influence significantly moderated the positive relationship between store-level promotions and impulse purchase; the high-normative-influence group showed greater impulsive purchase tendencies $(\beta=0.34, \mathrm{t}=2.68)$ than the low-normativeinfluence group $(\beta=0.29, \mathrm{t}=2.56)$ supporting $\mathrm{H}_{7 \mathrm{a}}$. With regards to $\mathrm{H}_{7 \mathrm{~b}}$, a significant moderating impact of normative influence was found on the relationship between brand equity and impulse purchase. The high-normative-influence group demonstrated a strong moderating impact $(\beta=0.50, \mathrm{t}=3.40)$, and the low-normative-influence group showed a nonsignificant impact. Significant impact of normative influence was found between price consciousness and impulse purchase; however, the low-normative-influence group showed high impulsive purchase behavior $(\beta=0.60, \mathrm{t}=3.39)$.

\section{Discussion and Conclusions}

This study examines the direct and interactive effects of store level promotions, brand equity and price consciousness on impulse purchase. The moderating role of category familiarity and normative influence on impulse purchase is also examined. The findings emphasize the need to study the influence of marketing variables together with moderating effects on impulse purchases rather than examining them in isolation. The study contributes towards the understanding of impulse buying behavior in the following ways: 
The research findings demonstrate that store-level promotions have a weak direct impact on impulse purchase. The weak direct impact also implies that store-level promotions may not be highly profitable for retailers for attracting and retaining customers. This research result concurs with the finding of Srinivasan et al. (2004) who observed that promotions have a predominantly positive impact on manufacturer revenue. However, the impact of store-level promotions on retailer revenue and margin is mixed. The findings from this study suggest that retailers should use store-level promotions in moderation. The study also demonstrates the importance of brand building in driving impulse purchase, particularly when the category familiarity is low as well as when the normative influences are high. The results of the study show that when consumers are less aware of the category, the brand equity acts as one of the major decision making cues. The research findings also indicate that at an overall level, price consciousness is a non-significant predictor of impulse purchase. The research findings contradict previous research on price consciousness and impulse purchase. This research result is probably due to the nature of the product (low-end electronic goods rather than fast moving consumer goods), type of respondents (real consumers instead of students), and method of eliciting response (mall-intercept instead of imaginary purchase scenarios) in this study, in contrast to previous studies.

While the findings illustrate the significant direct effects of the managementcontrolled factors (i.e. store-level promotions and brand equity) on impulse purchase, the findings relating to the interactive effects of store-level promotions on impulse purchase are also worthy of notice. Although the direct impact of store-level promotions on impulse purchase behavior is weak, the results of this study indicate that store-level promotions act as a catalyst in influencing the relationship between price consciousness and impulse purchase behavior. The result suggests that store-level promotions make consumers think that they are getting a better bargain and, in turn, increase their impulsive tendencies. Store-level 
promotions extend the critical role played by brand equity as the promotion significantly moderates the relationship between brand equity and impulse purchase. Chandon et al. (2009) found that brand manufacturers are spending an increasing amount of their total promotion budget in-store. The results of this study provide added evidence that the increase in in-store spending budget by brand manufacturers may well be justified, given that brand equity is one of the most important consideration stimuli for many consumers as well as its effects are significantly pronounced when associated with store-level promotions. The research results also further the argument put forward by Srinivasan et al. (2004) that store-level promotions for branded goods can be a potent tool to drive impulse purchase and in turn increase sales revenue.

With regards to store-level promotions, as hypothesized, the group with low category familiarity was more influenced by store-level promotions than the group with high category familiarity. This research finding suggests that by using store-level promotions, retailers and manufacturer may be able to specifically attract consumers with low category familiarity. With respect to the moderating influence of normative influence on the relationship between store-level promotions and impulse purchase, the group with high-normative-influence demonstrated a stronger effect than the group with low-normative-influence. However, the effect was significant in both cases. This research finding, when corroborated with the overall impact of store-level promotions, suggests two important strategic implications for retail managers. First, retail managers can use store-level promotions as a segmentation tool (i.e., for the group with low category familiarity), and second, they can use the store-level promotions as a generic tool to increase sales (i.e. by focusing on normative influence aspects). Store-level promotions may offer better returns with less investment because of the targeted effort and reduce the need for continuous promotions as observed in most markets. 
The research results indicate that consumers with low category familiarity are more influenced by brand equity than consumers with high category familiarity. Additionally, high-normative-influence groups are more persuaded by brand equity than the lownormative-influence groups. These research findings highlight how consumers are influenced in the presence of other external stimuli. It may be that the consumers with low category familiarity are less aware of the competitive brand positioning in that specific category, and therefore a known branded product available with a promotion may increase their sense of getting a better bargain, which in turn, causes them to act impulsively. In this regard, this study suggests that if managers can build an in-store branding campaign focusing on social desirability, it is likely to drive impulse purchase associated with that particular brand at instore level. The findings related to price consciousness provide a notable change when category familiarity and normative influence moderate the relationship between store-level factors. Both low- and high-familiarity consumers and low -normative-influence groups are found to be price conscious. However, the low-familiarity and low-normative-influence consumers are found to be more price-conscious. This research finding reveals that retail managers can use clear segmentation strategies with regards to these consumer groups. The consumers with low category familiarity and low normative influence will react highly impulsively in the presence of price deals. Therefore, a firm that creates a profile of lowfamiliarity/low-normative-influence consumers can save precious organizational resources by specifically targeting this consumer group with price deals instead of generic price deals for all.

This study makes three important contributions overall. Grewal et al. (1998) observe that consumers hardly take decisions based on a single stimulus. Consumers' decisions are based on complex interactions between various stimuli. While prior studies conceptually and empirically demonstrate the direct influence of various factors on impulse purchase (Rook 
and Fisher, 1995; Inman et al., 2009), this study incorporates the direct and interactive effects of store-level stimuli on consumer impulse purchase. For example, a direct effects study could have concluded that store-level promotions have a weak impact on driving impulse purchase. However, such a study would have missed out on the significant moderating influence of store-level promotions on brand equity and price consciousness. Similarly, price consciousness may not be a significant direct influencer for impulse purchase but in the presence of a store-level promotion, can become highly significant. These research results demonstrate the importance of simultaneous examination of interplay between different consumer and store level variables, which in turn, can help retail managers and manufacturers take informed decisions. The study also demonstrates the significant moderating influence of category familiarity and normative influences on consumer impulse purchase. This research finding provides substantial segmentation opportunities for manufacturers and retailers at the store-level and also in shaping and driving consumers' impulse purchase behavior.

Although the study offers some noteworthy insights into the influence of store-level promotions, price consciousness, and brand equity on consumers' impulse purchase behavior, the findings should be cross-validated using diverse product categories and in other cultural contexts. Other factors may also influence consumers' impulsive purchases, such as retail atmosphere, deal proneness, monetary versus non-monetary promotions, and contextual factors. A particularly worthwhile issue could be the moderating influence of perceived value of the product category and involvement of consumers. For measuring the impact of storelevel promotions, future studies could also look into the differential impact of hedonic and utilitarian dimensions. A comparative study using different industries with low and high value and involvement could provide many insights with regards to impulse purchase.

\section{References}


Aaker DA. 1996. Measuring brand equity across products and markets. California Management Review 38 (3), 102-120.

Aaker DA. 1991. Managing Brand Equity. New York: The Free Press.

Abratt R, Goodey SD. 1990. Unplanned buying and in-store stimuli in supermarkets. Managerial and Decision Economics 11: 111-121.

Ailawadi KL, Beauchamp JP, Donthu N, Gauri DK, and Shankar V. 2009. Communication and promotion decisions in retailing: a review and directions for future research. Journal of Retailing 85 (1): 42-55.

Ailawadi KL, Harlam BA, Cesar J, and Trounce D. 2006. Promotion profitability for a retailer: the role of promotion, brand, category, and store characteristics. Journal of Marketing Research 43 (4): 518-535.

Ailawadi KL, Harlam B. 2004. An empirical analysis of the determinants of retail margins: the role of store-brand share. Journal of Marketing 68 (1): 147-165.

Ajzen I. 1991. The theory of planned behavior. Organizational Behavior and Human Decision Processes 50: 179-211.

Alford BL, Biswas A. 2003. The effects of discount level, price consciousness and sale proneness on consumers' price perception and behavioral intention. Journal of Business Research 55 (9): 775-783.

Batra R, Sinha I. 2000. Consumer-level factors moderating the success of private label brands. Journal of Retailing 76 (2): 175-191.

Bearden WO, Netemeyer RG, and Teel JE. 1989. Measurement of consumer susceptibility to interpersonal influence. Journal of Consumer Research 15 (4): 473-481.

Blattberg RC, Wisniewski KJ. 1989. Price induced patterns of competition. Marketing Science 8 (Fall), 291-309.

Chandon P, Hutchinson JW, Bradlow ET, and Young SH. 2009. Does in-store marketing work? Effects of the number and position of shelf facings on brand attention and evaluation at the point of purchase. Journal of Marketing 73 (6): 1-17.

Chandon P, Wansink B, and Laurent G. 2000. A benefit congruency framework of sales promotion effectiveness. Journal of Marketing 64 (4): 65-81.

Cox KK. 1970. The effect of shelf space upon sales of branded products. Journal of Marketing Research 7: 55-58.

Durbach IN, Stewart TJ. 2009. Using expected values to simplify decision making under uncertainty. Omega 37: 312-330.

Dyson P, Farr A and Hollis NS. 1996. Understanding, measuring and using brand equity. Journal of Advertising Research 36 (6): 9:21. 
Fornell C, Larcker DF. 1981. Evaluating structural equation models with unobservable variables and measurement error. Journal of Marketing Research 18 (1): 39-50.

Garretson JA, Burton S. 2003. Highly coupon and sale prone consumers: benefits beyond price savings. Journal of Advertising Research 43: 162-172.

Graeff TR. 2007. Reducing uninformed responses: the effects of product-class familiarity and measuring brand knowledge on surveys. Psychology and Marketing 24: 681-702.

Grewal D, Krishnan R, Baker J, and Borin N. 1998. The effect of store name, brand name and price discounts on consumers' evaluations and purchase intentions. Journal of Retailing 74: 331-352.

Hunt DM, Radford SK, and Evans KR. 2013. Individual differences in consumer value for mass customized products. Journal of Consumer Behaviour, 12: 327-336.

Inman JJ, Winer RS, and Ferraro R. 2009. The interplay among category characteristics, customer characteristics, and customer activities on in-store decision making. Journal of Marketing 73 (5): 19-29.

Kamakura WA, and Kang W. 2007. Chain-wide and store-level analysis for cross-category management. Journal of Retailing, 83 (2): 159-170.Keller KL. 1993. Conceptualizing, measuring, and managing customer-based brand equity. Journal of Marketing 57: 1-22.

Lastovicka JL, Bettencourt LA, Hughner RS, and Kuntze RJ. 1999. Lifestyle of the tight and frugal: theory and measurement. Journal of Consumer Research 26: 85-98.

Lichtenstein DR, Ridgway NM, and Netemeyer RG. 1993. Price perceptions and consumer shopping behavior: a field study. Journal of Marketing Research 30 (2): 234-245.

Mourali M, Laroche M, and Pons F. 2005. Individualistic orientation and consumer susceptibility to interpersonal influence. Journal of Services Marketing, 19: 164-173.

Narasimhan C, Neslin SA, and Sen SK. 1996. Promotional elasticities and category characteristics. Journal of Marketing 60 (2): 17-30.

Parker PM, Tavassoli NT. 2000. Homeostasis and consumer behavior across cultures. International Journal of Research in Marketing 17: 33-53.

Peck J, Childers TL. 2006. If I touch it I have to have it: individual and environmental influences on impulse purchasing. Journal of Business Research 59 (6): 765-769.

Pilley J. 2008. Impulse purchasing from points of purchase. London: Ezinearticles.com. Available at: http://ezinearticles.com/?Impulse-Purchasing-From-Points-ofPurchase\&id=1643184 [accessed on 29 August 2009].

Ping RA. 1995. A parsimonious estimating technique for interaction and quadratic latent variables. Journal of Marketing Research 32 (3): 336-347. 
Rao AR, Monroe KB. 1988. The moderating effect of prior knowledge on cue utilization in product evaluations. Journal of Consumer Research 15: 253-264.

Rao AR, SiebenWA. 1992. The effect of prior knowledge on price acceptability and the type of information examined. Journal of Consumer Research 19 (2): 256-270.

Rangaswamy A, Burke R, and Olivia TA. 1993. Brand equity and the extendibility of brand names. International Journal of Research in Marketing 10 (March), 61-75.

Ratneshwar S, and Chaiken S. 1991. Comprehension's role in persuasion: The case of its moderating effect on the persuasive impact of source cues. Journal of Consumer Research, 18 (1): 52-62.

Rook DW Fisher RJ. 1995. Normative influences on impulsive buying behavior. Journal of Consumer Research 22 (December): 305-313.

Rust RT, Zeithaml VA and Lemon KN. 2004. Customer centered brand management. Harvard Business Review September, 1-10.

Shukla P. 2011. Impact of interpersonal influences, brand origin and brand image on luxury purchase intentions: Measuring interfunctional interactions and a cross-national comparison. Journal of World Business, 46: 242-252.

Shukla P. 2010. Status consumption in cross-national context: socio-psychological, brand and situational antecedents. International Marketing Review 27 (1): 108-129.

Simonson I, Huber J, and Payne J. 1988. The relationship between prior knowledge and information acquisition order. Journal of Consumer Research 14 (March), 566-578.

Sinha I, Batra R. 1999. The effect of consumer price consciousness on private label purchase. International Journal of Research in Marketing 16 (3): 237-251.

Slotegraaf RJ, Pauwels K. 2008. The impact of brand equity and innovation on the long-term effectiveness of promotions. Journal of Marketing Research, 45 (3): 293-306.

Srinivasan S, Pauwels K, Hanssens DM, and Dekimpe MG. 2004. Do promotions benefit manufacturers, retailers, or both? Management Science, 50 (5): 617-629.

Srivastava R, Shocker AD. 1991. Brand equity: a perspective on its meaning and measurement. Working Paper Series, Report No. 91-124. Cambridge, MA: Marketing Science Institute.

Starr MK, Rubinson JR. 1978. A loyalty group segmentation model for brand purchasing simulation. Journal of Marketing Research 15 (August), 378-383.

Thaler R. 1985. Mental accounting and consumer choice. Marketing Science 4: 199-214.

Verhoef PC, Lemon KN, Parasuraman A, Roggeveen A, Tsiros M, and Schlesinger LA. 2009. Customer experience creation: Determinants, dynamics and management strategies. Journal of Retailing, 85 (1): 31-41. 
Weun S, Jones MA, and Beatty SE. 1998. Development and validation of the impulse buying tendency scale. Psychological Reports 82 (3): 1123-1133.

Walters RG. 1991. Assessing the impact of retail price promotions on product substitution, complementary purchase, and interstore sales displacement. Journal of Marketing $\mathbf{5 5}$ (April): $17-28$.

Walters RG, Mackenzie SB. 1988. A structural equations analysis of the impact of price promotions on store performance. Journal of Marketing Research 25 (February): 51-63.

Yoo B, Donthu N. 2001. Developing and validating a multi-dimensional consumer-based brand equity scale. Journal of Business Research 52 (1): 1-14. 
Figure 1: Model overview

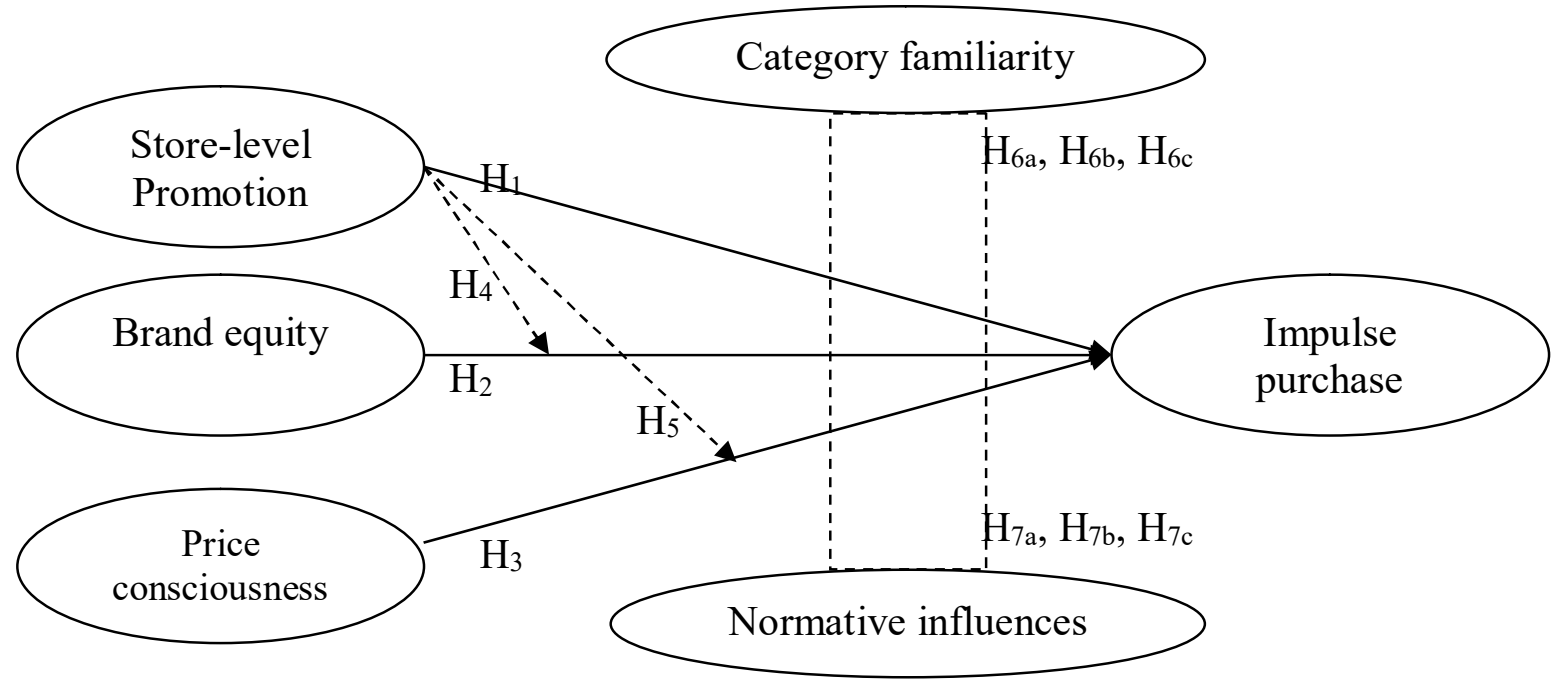

$\rightarrow$ Direct relationships

$\ldots$ Moderated relationship 
Table 1: Measurement scale items

\begin{tabular}{|c|c|c|c|}
\hline Scale items & $\begin{array}{c}\text { Item } \\
\text { reliability }\end{array}$ & CR & AVE \\
\hline Store-level promotions & & 0.78 & 0.60 \\
\hline I buy electronic products if the store highlights an attractive promotion. & 0.68 & & \\
\hline \multicolumn{4}{|l|}{ Promotions available in electronic products stores... } \\
\hline ...make me buy products spontaneously. & 0.70 & & \\
\hline ...increase my desire to buy electronic products. & 0.69 & & \\
\hline ...entice me to buy things on the spur of the moment. & 0.53 & & \\
\hline ...remind me that I need the electronic product. & 0.62 & & \\
\hline Brand equity & & 0.80 & 0.67 \\
\hline $\begin{array}{l}\text { It makes sense to buy a reputable brand of electronics instead of any other } \\
\text { lower category brand, even if they are the same. }\end{array}$ & 0.55 & & \\
\hline $\begin{array}{l}\text { I will not buy lower category brand, if a reputable brand of electronics is } \\
\text { available in store. }\end{array}$ & 0.69 & & \\
\hline $\begin{array}{l}\text { If there is another brand as good as a reputable brand, I still prefer to buy } \\
\text { the reputable brand. }\end{array}$ & 0.75 & & \\
\hline $\begin{array}{l}\text { I like to know what electronic brands and products make good impression } \\
\text { on others. }\end{array}$ & 0.82 & & \\
\hline Price consciousness & & 0.81 & 0.66 \\
\hline $\begin{array}{l}\text { I am not willing to go to extra effort to find lower priced electronic } \\
\text { products. (R) }\end{array}$ & 0.64 & & \\
\hline $\begin{array}{l}\text { I shop at more than one store to take advantage of low prices for } \\
\text { electronic products. }\end{array}$ & 0.78 & & \\
\hline $\begin{array}{l}\text { The money saved by finding a lower priced electronic product is usually } \\
\text { not worth the time and effort. (R) }\end{array}$ & 0.72 & & \\
\hline $\begin{array}{l}\text { I would never shop at more than one store to find low prices for electronic } \\
\text { products. (R) }\end{array}$ & 0.69 & & \\
\hline $\begin{array}{l}\text { The time it takes to find low priced electronic products is usually not } \\
\text { worth the effort. (R) }\end{array}$ & 0.52 & & \\
\hline Category familiarity & & 0.73 & 0.56 \\
\hline $\begin{array}{l}\text { I have enough knowledge about electronic products that, I don't need to } \\
\text { actually try a brand to know how good it is. }\end{array}$ & 0.69 & & \\
\hline $\begin{array}{l}\text { Prior knowledge about the electronic products gives me information } \\
\text { about all the features in buying it. }\end{array}$ & 0.66 & & \\
\hline I enjoy purchasing electronic products for which I know little. (R) & 0.72 & & \\
\hline Normative influence & & 0.79 & 0.65 \\
\hline $\begin{array}{l}\text { It says something to people when you buy the high technological version } \\
\text { of an electronic product. }\end{array}$ & 0.88 & & \\
\hline $\begin{array}{l}\text { I often consider buying an electronic product because it is new and } \\
\text { fashionable and others like it. }\end{array}$ & 0.63 & & \\
\hline $\begin{array}{l}\text { I enjoy the prestige which stems from buying high-priced electronic } \\
\text { products. }\end{array}$ & 0.74 & & \\
\hline $\begin{array}{l}\text { Others make judgments about me by the kinds of electronic products I } \\
\text { buy. }\end{array}$ & 0.50 & & \\
\hline Impulse purchase & & 0.77 & 0.66 \\
\hline \multicolumn{4}{|l|}{ Reflecting on your electronic products purchase.. } \\
\hline ...I make unplanned purchases regularly. & 0.76 & & \\
\hline
\end{tabular}


...I buy ones that I had not intended to purchase.

...It is fun to buy electronic products spontaneously.

0.58

$(\mathrm{R})=$ reverse coded . 
Table 2: Correlation matrix

\begin{tabular}{|l|l|l|l|}
\hline & $\begin{array}{l}\text { Store-level } \\
\text { promotions }\end{array}$ & Brand equity & $\begin{array}{l}\text { Price } \\
\text { consciousness }\end{array}$ \\
\hline Store-level promotions & 0.78 & & \\
\hline Brand equity & 0.08 & 0.81 & \\
\hline Price consciousness & 0.09 & 0.54 & 0.81 \\
\hline
\end{tabular}

Note. Values in italics on the main diagonal are the square root of AVE of the latent variable. 
Table 3: Fit measures for the models

\begin{tabular}{|l|l|l|l|l|l|l|l|}
\hline & $\boldsymbol{\chi}^{\mathbf{2}}$ & df & RMSEA & GFI & NNFI & CFI & $\boldsymbol{\chi}^{\mathbf{2}} / \mathbf{d f}$ \\
\hline Restricted & 206.32 & 103 & 0.070 & 0.91 & 0.91 & 0.93 & 2.00 \\
\hline Unrestricted & 166.96 & 101 & 0.048 & 0.96 & 0.96 & 0.97 & 1.65 \\
\hline
\end{tabular}


Table 4: Path coefficients

\begin{tabular}{|l|l|l|}
\hline Path coefficients & Estimates & T-values \\
\hline Store-level promotions $\rightarrow$ impulse purchase & 0.13 & $2.11^{*}$ \\
\hline Price consciousness $\rightarrow$ impulse purchase & -0.07 & -0.70 \\
\hline Price consciousness $\times$ store-level promotions $\rightarrow$ impulse purchase & 0.66 & $5.93^{*}$ \\
\hline Brand equity $\rightarrow$ impulse purchase & 0.39 & $2.31^{*}$ \\
\hline Brand equity $\times$ store-level promotions $\rightarrow$ impulse purchase & 0.19 & $3.04^{*}$ \\
\hline$*$ Relationship is significant at $p<0.01$. & \multicolumn{2}{|l}{} \\
\hline
\end{tabular}


Table 5: Comparison of unconstrained and constrained models for moderating factors

\begin{tabular}{|l|l|l|l|l|l|l|l|}
\hline \multicolumn{2}{|l|}{ Category familiarity } \\
\hline & $\boldsymbol{\chi}^{\mathbf{2}}$ & df & RMSEA & GFI & NNFI & CFI & $\boldsymbol{\chi}^{\mathbf{2} / \mathbf{d f}}$ \\
\hline Restricted & 214.98 & 132 & 0.076 & 0.92 & 0.87 & 0.90 & 1.63 \\
\hline Unrestricted & 162.45 & 119 & 0.050 & 0.95 & 0.95 & 0.96 & 1.37 \\
\hline Normative influences \\
\hline Restricted & 207.44 & 127 & 0.065 & 0.90 & 0.94 & 0.95 & 1.63 \\
\hline Unrestricted & 169.53 & 114 & 0.058 & 0.91 & 0.96 & 0.97 & 1.49 \\
\hline
\end{tabular}


Table 6: Path coefficients for the moderator variables

\begin{tabular}{|l|l|l|l|l|l|l|l|l|l|}
\hline & \multicolumn{3}{|c|}{ Category familiarity } & \multicolumn{3}{c|}{ Normative influence } \\
\hline & \multicolumn{2}{|c|}{ High } & \multicolumn{2}{c|}{ Low } & \multicolumn{3}{c|}{ High } & \multicolumn{3}{c|}{ Low } \\
\hline & Est. & t-value & Est. & t-value & Est. & t-value & Est. & t-value \\
\hline Store-level promotions $\rightarrow$ IP & 0.13 & 1.30 & 0.32 & $2.11^{*}$ & 0.34 & $2.68^{*}$ & 0.29 & $2.56^{*}$ \\
\hline Brand equity $\rightarrow$ IP & 0.23 & 1.01 & 0.26 & $1.98^{*}$ & 0.50 & $3.40^{*}$ & 0.08 & 0.70 \\
\hline Price consciousness $\rightarrow$ IP & 0.43 & $2.34^{*}$ & 0.52 & $2.60^{*}$ & 0.21 & 1.74 & 0.60 & $3.39^{*}$ \\
\hline $\begin{array}{l}\text { IP }=\text { impulse purchase } \\
* \text { relationship significant at } \mathrm{p}<0.01\end{array}$ \\
\hline
\end{tabular}

